\title{
The militarization of responses to COVID-19 in Democratic
} Latin America

\author{
Anaís Medeiros Passos 1 \\ Igor Acácio 2 \\ 1 Universidade Federal de Santa Catarina / Departamento de Sociologia e Ciência Política, Florianópolis / SC - Brazil \\ 2 University of California / Department of Political Science, Riverside / CA - United States
}

Latin America has been severely affected by the COVID-19 pandemic, prompting its governments to take action. In this context, countries within Latin America have used their armed forces for an array of tasks to serve citizens. But how militarized is the response to COVID-19 in Latin America? This paper proposes a typology of tasks provided by the armed forces as a response to COVID-19. The descriptive findings allow us to map these tasks, attributing scores to the fourteen Latin American democracies. We also show evidence for the potential consequences of some tasks. Policing the streets to enforce stay-at-home orders may lead to the military committing human rights violations, assuming eminently civilian posts to manage the public health crisis can result in long term implications for the civil-military balance that are detrimental to the democratic control over the military.

Keywords: COVID-19; global pandemic; militarization; civil-military relations; Latin America; military missions.

\section{A militarização das respostas à COVID-19 nas democracias Latino-americanas}

A América Latina foi gravemente afetada pela pandemia global COVID-19, o que estimulou a resposta dos seus governos. Nesse contexto, esses países têm utilizado suas forças armadas para uma série de tarefas a serviço dos cidadãos. Mas quão militarizada é a resposta à COVID-19 na América Latina? Este artigo propõe uma tipologia de tarefas solicitadas a esses militares em resposta à COVID-19. Os resultados descritivos nos permitem mapear as várias tarefas que os militares estão sendo encarregados de fazer, atribuindo notas às quatorze democracias latinoamericanas. Também mostramos evidências das consequências potenciais de algumas tarefas. Pode-se observar que há risco de violação dos direitos humanos quando militares são encarregados de policiar as ruas para fazer cumprir as ordens de permanência em casa. Ainda, quando os militares assumem cargos eminentemente civis na administração da crise de saúde pública vislumbram-se implicações de longo prazo em relação ao equilíbrio civil-militar, o que prejudica o controle democrático sobre os militares.

Palavras-Chave: COVID-19; pandemia global; militarização; relações civil-militares; América Latina; missões militares.

\section{La militarización de las respuestas a la COVID-19 en las democracias latinoamericanas}

América Latina se ha visto gravemente afectada por la pandemia mundial de COVID-19, lo que ha llevado a sus gobiernos a tomar medidas. En este contexto, estos países han utilizado sus fuerzas armadas para una serie de tareas al servicio de la ciudadanía. Pero ¿qué tan militarizada es la respuesta a la COVID-19 en América Latina? Este artículo propone una tipología de tareas solicitadas a esas fuerzas armadas como respuesta a la COVID-19. Los hallazgos descriptivos permiten mapear las diversas tareas que se les han asignado a los militares, atribuyendo puntajes a las catorce democracias latinoamericanas. También mostramos evidencia de las posibles consecuencias de algunas tareas. Al vigilar las calles para hacer cumplir las órdenes de confinamiento, los militares pueden cometer violaciones a los derechos humanos, al asumir puestos eminentemente civiles para gestionar la crisis de salud pública, puede haber implicaciones a largo plazo para el equilibrio cívico-militar que son perjudiciales para el control democrático sobre los militares.

Palabras-clave: COVID-19; pandemia global; militarización; relaciones cívico-militares; América Latina; misiones militares. 


\section{THE GLOBAL PANDEMIC OF COVID-19 AND THE NEED FOR MILITARY DEPLOYMENT}

Latin America has been severely impacted by the COVID-19 global pandemic. As of May 27, about 43,248 coronavirus related deaths were reported and, as of May 26, 700254 cases $^{1}$, which makes it today's epicenter of the sanitary crisis. ${ }^{2}$ The region invests poorly in health services - about 949 dollars per capita, which is four times less than the expenditure of OECD (Organization of Economic Cooperation and Development) countries (Lago, 2020) - and provides insalubrious housing for the most disadvantaged sectors of the population. Due to these factors, Latin American countries have been struggling to tackle the coronavirus outbreak.

\section{GRAPH 1 TOTAL COVID-19 CASES IN 26 MAY 2020}

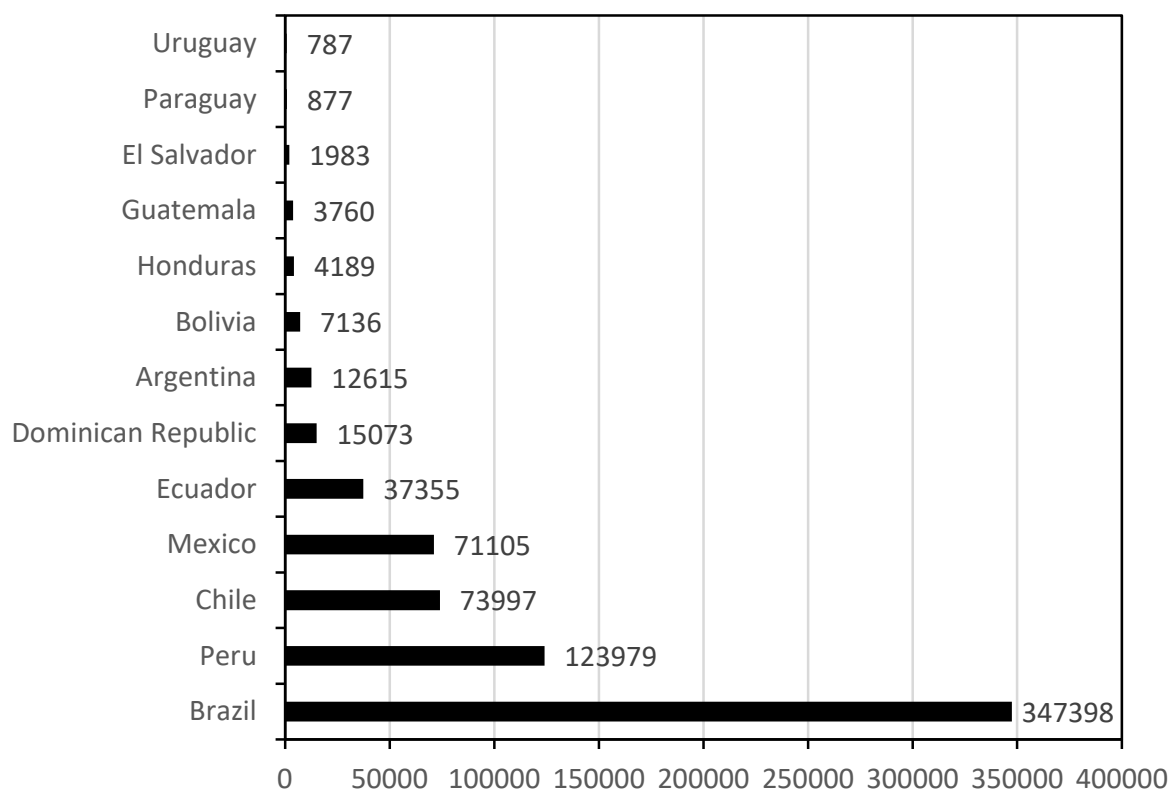

Source: Our World in Data (2020).

Whether by its own initiative or civilian demand, the military is filling a void in state capacity to respond to the pandemic. This paper aims to map out the process of militarization of governmental responses to the global pandemic of COVID-19 in Latin America. We will do so by devising a typology to measure the level of militarization of Latin American democracies' policies to counter COVID-19. By militarization, we mean the systematic use of the military to execute missions in support or replacement of civilian-led efforts. This within-regional analysis will allow us to identify

\footnotetext{
${ }^{1}$ Data specifically for the countries included in this study.

${ }^{2}$ Data retrieved from https://ourworldindata.org/grapher/total-cases-covid-19?time=2020-01-22..2020-05-15\&country=ARG $+B O L+B$ $\mathrm{RA}+\mathrm{CHL}+\mathrm{COL}+\mathrm{ECU}+\mathrm{SLV}+\mathrm{GTM}+\mathrm{HND}+\mathrm{MEX}+\mathrm{NIC}+\mathrm{PRY}+\mathrm{PER}+\mathrm{URY}$
} 
similarities and differences between countries. We will also provide evidence of human rights abuses for countries that deployed their militaries to enforce "stay-at-home" orders.

Methodologically, this is a middle- $\mathrm{N}$ qualitative descriptive study to depict the militarization of governmental responses to the pandemic. The article draws from official decrees, websites of the ministries of defense and armed forces' branch commands, as well as their social media accounts. Cases included are the following Latin American democracies with armed forces: Argentina, Bolivia, Brazil, Chile, Colombia, Dominican Republic, Ecuador, El Salvador, Guatemala, Honduras, Mexico, Paraguay, Peru, and Uruguay. The material was collected between March 1 ${ }^{\text {st }}, 2020$ and May 25, 2020.

\section{MILITARY MISSIONS IN LATIN AMERICA AND A TYPOLOGY OF MILITARY MISSIONS IN RESPONSE TO COVID-19}

In Latin America, there is a history of military activity as a tool for state capacity. In the $19^{\text {th }}$ century, soldiers erected bridges, opened and paved roads to connect isolated areas to the more developed ones, and ran strategic border towns in different sites of Latin America (Loveman, 1999). In the 20 ${ }^{\text {th }}$ century, military missions expanded to include running public enterprises and performing civic-social actions. Today, the military are often required to perform police roles in the fight against organized crime, as well as in the relief of humanitarian crisis and natural disasters.

However, in some instances, using the military in large scale to support civilian efforts to fight off the pandemic may be problematic. Whereas some activities are more compatible with military training, others tend to increase the likelihood of misdeeds and misbehavior by military personnel against citizens. In other words, militaries are more effective the closer the new missions are to their previously developed organizational capabilities (Pion-Berlin, 2016).

Summarized on Box 1, we theorize that there are six issue areas that may require military involvement in the governmental responses to the global pandemic: Border Security, Logistics, Medical Care, Defense Industry, Crisis-Management and Policing. Some of these tasks, such as border security, logistics, medical care and defense industry are more suitable because they draw on the military's organizational capabilities (Acácio, 2020). Others, such as the appointment of military officers for crisis-management positions or the involvement of the military in policing missions to enforce stay-at-home orders come with potential repercussions such as a higher potential for human rights violations and serious implications for democratic control over the military, compromising the quality of democratic regimes (Diamint, 2015).

Border Security pertains to the deployment of the military at the border. In Latin America, there is a large variation on who is responsible for border security, but the literature regards border security missions as the closest to the classical missions of external defense that can exist (Pion-Berlin, 2016). Logistical Support comprises the transportation and distribution of supplies to hospitals and individuals. It makes the military use its great logistical capacity - after all, it is with efficient logistics that modern conflicts are overcome. The logistical support is comprised of the distribution of medical supplies and food, centralized in hospitals and warehouses. This task also involves soldiers distributing supplies directly to individuals and efforts of repatriation of citizens abroad. 


\begin{tabular}{|c|c|c|c|}
\hline & Low $=1$ & Medium $=2$ & High $=3$ \\
\hline Border Security & $\begin{array}{l}\text { Low or no numbers of troops } \\
\text { sent to the border. }\end{array}$ & $\begin{array}{l}\text { Troops sent to the border in a } \\
\text { considerable number. Aerial } \\
\text { and/or Naval surveillance } \\
\text { heightened. }\end{array}$ & $\begin{array}{l}\text { Troops sent in high numbers. } \\
\text { Special mandates to act on } \\
\text { border security, including aerial } \\
\text { and naval surveillance. }\end{array}$ \\
\hline Logistical & $\begin{array}{l}\text { Little to no involvement distributing } \\
\text { food or supplies to either hospitals } \\
\text { or individuals. }\end{array}$ & $\begin{array}{l}\text { Involvement with distribution of } \\
\text { medical supplies or food, but in } \\
\text { moderate amounts. }\end{array}$ & $\begin{array}{l}\text { Taking over supply and } \\
\text { distribution of medical supplies } \\
\text { and food to several. }\end{array}$ \\
\hline Medical Care & $\begin{array}{l}\text { Setting up small amount of field } \\
\text { hospitals, little or no existing } \\
\text { military hospitals. Little to no } \\
\text { medical testing. }\end{array}$ & $\begin{array}{l}<1000 \text { hospital beds } \\
\text { made available, either with } \\
\text { field hospitals or military } \\
\text { hospitals. Some medical testing. }\end{array}$ & $\begin{array}{l}\text { Thousands of hospital beds } \\
\text { made available in physical } \\
\text { or field. Taking over medical } \\
\text { testing. }\end{array}$ \\
\hline Defense Industry & $\begin{array}{l}\text { Production of low-complexity } \\
\text { medical supplies (Masks, } \\
\text { Alcohol Gel) in a limited scale } \\
\text { (production of units a day } \\
<1000 \text { ). }\end{array}$ & $\begin{array}{l}\text { Production of low-complexity } \\
\text { medical supplies in a medium } \\
\text { scale (Masks, Alcohol Gel) } \\
\text { (1000<production of units a } \\
\text { day <10000). }\end{array}$ & $\begin{array}{l}\text { Production of large amounts } \\
\text { of medical supplies, including } \\
\text { masks, alcohol gel and medicine, } \\
\text { in a large scale (production of } \\
\text { units a day> 10.000). }\end{array}$ \\
\hline Crisis-management & $\begin{array}{l}\text { Military has little involvement in } \\
\text { managing the crisis. Civilians } \\
\text { hold key positions in the Ministry } \\
\text { of Health and emergency } \\
\text { management authorities. }\end{array}$ & $\begin{array}{l}\text { Military officers are appointed } \\
\text { to key positions in the Ministry } \\
\text { of Health, but the Health } \\
\text { Minister is a civilian. }\end{array}$ & $\begin{array}{l}\text { Military officers appointed to } \\
\text { key positions in the Ministry } \\
\text { of Health and in crisis- } \\
\text { management, including to lead } \\
\text { this institution. }\end{array}$ \\
\hline Policing & $\begin{array}{l}\text { Troops deployed in public } \\
\text { security in support of police } \\
\text { bodies and in small numbers. } \\
\text { Little contact with population, } \\
\text { little discretion. }\end{array}$ & $\begin{array}{l}\text { Troops patrol the street in limited } \\
\text { scale (> } 1000 \text { soldiers deployed } \\
\text { on street). Some contact with } \\
\text { citizens, but the military play a } \\
\text { secondary role to the police. }\end{array}$ & $\begin{array}{l}\text { Intensively deployed in police } \\
\text { tasks. State of exception. } \\
\text { There are military checkpoints } \\
\text { within the national territory. }\end{array}$ \\
\hline
\end{tabular}

Sources: Elaborated by the authors based on the websites of the ministries of defense and armed forces' branch commands in Argentina, Bolivia, Brazil, Chile, Colombia, Dominican Republic, Ecuador, El Salvador, Guatemala, Honduras, Mexico, Paraguay, Peru, and Uruguay.

Setting up field hospitals is something that the armed forces are not only trained and equipped to do but are also able to by taking advantage of its built-in organizational capacities. In addition to constructing field hospitals, the category Medical Care also requires getting the military involved in medical triage and medical testing, as well as patient care. Defense Industry comprises the use of the defense industry to produce medical supplies. Though it can be argued that deviating the defense industry to non-defense matters decreases its efficiency and might compromise national power in the medium term (Grimes \& Pion-Berlin, 2019) in case of extreme need, such policies may be warranted without further implications.

Two additional categories pertain to activities that the military can be tasked with but that hold potentially harmful impacts for both the population and for civil-military relations. Crisis- 
management includes different modalities of crisis-management positions held by the military. In the context of an acute sanitary crisis, civilian authorities may be tempted to appoint military officers to political positions for managing the situation. As the scholarship has exhaustively argued, a high level of military involvement with non-military affairs will affect the civil-military balance, compromising the quality of democracy and undermining the civilian control over the former (Amorim, 2015).

Finally, Policing involves the use of military forces in an array of police functions. Using the military for police tasks is problematic because the military's main mission is to eliminate external enemy forces, whereas policing involves the gradual use of force and close involvement with people (Campbell \& Campbell, 2010). The closer their involvement with the public when policing, the more likely human rights violations are to occur (Passos 2020; Pion-Berlin, 2016).

\section{DESCRIPTIVE RESULTS: MAPPING OUT MILITARIZATION OF GOVERNMENT RESPONSES TO COVID-19 IN LATIN AMERICA}

Consistent with academic reporting on the issue, the first point to be made is that no democracy in Latin America resisted the urge to draft their military for COVID-19 tasks (Red de Seguridad y Defensa de América Latina [RESDAL], 2020). Table 1 summarizes our descriptive results, according to the following classification: 1 (low), 2 (medium) and 3 (high).

Uruguay and Argentina used the military in a limited number of tasks. These countries have historically higher levels of control over the military; they rendered their armed forces accountable for the state-sponsored human rights violations during the military-led regimes of the 1960s and 1970s (Saint-Pierre, 2007). The military of these two countries are not engaged in tasks that imply an imminent risk for misdeeds and efficiency; they are, for the most part, providing medical care, acting in support of logistics and doing border security to contain the spread of the virus.

TABLE 1 SCORING LATIN AMERICAN DEMOCRACIES IN MILITARIZATION

\begin{tabular}{|c|c|c|c|c|c|c|c|}
\hline $\begin{array}{l}\text { Country/ } \\
\text { Category }\end{array}$ & $\begin{array}{l}\text { Border } \\
\text { security }\end{array}$ & $\begin{array}{l}\text { Medical } \\
\text { Care }\end{array}$ & Logistics & $\begin{array}{l}\text { Defense } \\
\text { Industry }\end{array}$ & Policing & $\begin{array}{c}\text { Crisis-management } \\
\text { delegation }\end{array}$ & $\begin{array}{c}\text { Total } \\
\text { Militarization }\end{array}$ \\
\hline Uruguay & 3 & 1 & 2 & 2 & 0 & 0 & 8 \\
\hline Argentina & 1 & 2 & 3 & 1 & 1 & 0 & 8 \\
\hline Dominican Republic & 2 & 1 & 0 & 3 & 3 & 0 & 9 \\
\hline Ecuador & 2 & 1 & 3 & 0 & 3 & 0 & 9 \\
\hline El Salvador & 3 & 2 & 2 & 0 & 3 & 0 & 10 \\
\hline Paraguay & 2 & 1 & 2 & 2 & 2 & 1 & 10 \\
\hline Mexico & 1 & 3 & 3 & 1 & 2 & 0 & 10 \\
\hline
\end{tabular}




\begin{tabular}{lccccccc}
$\begin{array}{l}\text { Country/ } \\
\text { Category }\end{array}$ & $\begin{array}{c}\text { Border } \\
\text { security }\end{array}$ & $\begin{array}{c}\text { Medical } \\
\text { Care }\end{array}$ & Logistics & $\begin{array}{c}\text { Defense } \\
\text { Industry }\end{array}$ & Policing & $\begin{array}{c}\text { Crisis-management } \\
\text { delegation }\end{array}$ & $\begin{array}{c}\text { Total } \\
\text { Militarization }\end{array}$ \\
Guatemala & 3 & 2 & 2 & 1 & 3 & 0 & 11 \\
Chile & 2 & 2 & 2 & 0 & 3 & 2 & 11 \\
Bolivia & 2 & 2 & 2 & 0 & 3 & 2 & 11 \\
Colombia & 3 & 2 & 3 & 2 & 2 & 0 & 12 \\
Peru & 3 & 2 & 2 & 1 & 3 & 2 & 13 \\
Brazil & 2 & 2 & 3 & 2 & 1 & 3 & 13 \\
Honduras & 3 & 2 & 3 & 2 & 3 & 0 & 13 \\
\hline
\end{tabular}

Note: The value " 0 " was attributed if no evidence was found of the country militarizing a given area.

Sources: Elaborated by the authors based on the websites of the ministries of defense and armed forces' branch commands in Argentina, Bolivia, Brazil, Chile, Colombia, Dominican Republic, Ecuador, El Salvador, Guatemala, Honduras, Mexico, Paraguay, Peru, and Uruguay.

In contrast, Peru, Brazil and Honduras have intensively deployed the military in an array of tasks, ranging from border security, medical care and logistics to policing and crisis-management. The defense industry was also mobilized to respond to the ongoing demands from the health sector, as well as developing alternative technologies. Peru and Honduras imposed curfews in mid-March (RESDAL, 2020). The military policed with close involvement with people to enforce curfews, operating free from civilian oversight. This condition is likely to aggravate the issue of state-sponsored violence that is present in these countries. Brazil has not sent its military in policing tasks, but its influential military has taken over several positions to manage the public health crisis while the country struggles with largest number of cases (see Graph 1).

In terms of Border Security, Colombia, Honduras, Peru and El Salvador were the most militarized cases. Since Ecuador is considered a COVID-19 hotspot, both Colombia and Peru have strengthened their border control with that country (Ministerio de Defensa de Peru, 2020a). 29,000 members of the military started guarding the Colombian borders (Presidencia de la República de Colombia, 2020). Both Peru and Colombia have recalled thousands of reservists for service in the armed forces as an emergency measure. As an intermediate case, the Dominican Republic has pursued some efforts to step up border vigilance with drones and by sending 600 troops (Listín Diário, 2020). In contrast, cases like Mexico and Argentina did not over-militarize their border.

Mexico and Colombia exemplify aspects of the militarization of medical care. In Colombia, 2000 beds were made available via campaign hospitals by the military, as well as three naval hospitals and three ships. The army has developed testing capacity to perform 200 tests daily (Agencia EFE, 2020). In stark comparison, the Dominican Republic only made available around 75 beds via its air force military hospital.

In terms of logistics, Argentina is proving to be one of the most efficient cases, exemplifying the extreme values in our typology. There, the military took over the activity of repatriation flights and distributed thousands of meals daily. Countries like Colombia have also been doing similar activities. The Colombian Air Force, as of April 4, 2020, distributed 23 tons of food and 96 thousand gallons of potable water (Saumeth, 2020). The Brazilian armed forces have distributed 1.5 tons of food to the 
population (Exército Brasileiro, 2020) and worked in several actions of support to the population known as Acões Cívico-Sociais (ACISO) (Grigoli, Silva \& Migon, 2020; Gröhs, Biavaschi ,\& Rodrigues, 2020). In contrast, there has been limited evidence that the Dominican Republic Armed Forces are being used for logistical support during this COVID-19 pandemic.

There is large variance in the defense industry. The Dominican Republic military has pledged to produce 200,000 masks and personal protective equipment. They also developed a decontamination device to be installed in public buildings (Fuerza Aérea de República Dominicana, 2020). In contrast, the Peruvian military has been developing the technology for a new form of more affordable respirators, but it is currently only a pilot program (Ministerio de Defensa de Peru, 2020b).

Regarding the management of the crisis, Brazil scores as the case with the highest military involvement in this dimension. In Brazil, military officers were appointed to about twenty positions in the Ministry of Health, and an Army General was nominated to be the interim Minister of Health in mid-May (Vargas, 2020). Bolivia, Peru and Chile display a medium involvement of the military with crisis-management. In Bolivia, a Rear-Admiral was appointed as head of the Comité de Operaciones de Emergencia Nacional (COEN), and in Peru, there are regional commands in Arequipa and Lambayeque led by high-ranking military officers in charge of managing the crisis (Gobierno del Peru, 2020; Ministerio de Defensa del Estado Pluracional de Bolivia, 2020). Since mid-march, Chile was divided into 16 emergency zones managed by high-ranking military officers (Ministerio del Interior y Seguridad Pública de Chile, 2020).

Paraguay has some involvement of the military with crisis-management at the Comisión Nacional de Prevención y Respuesta a Emergencias Biologicas (CONAPREB), but the Ministry of Health is led by a civilian. Several countries have no military involvement in managing the crisis. As this dimension is the most political one, this result could be explained in two ways: the concealment of information and the lack of interest. Military commanders may be less interested in taking the burden of managing the crisis, so information about this dimension, when it occurs, may be scarce. Therefore, further research is necessary.

Dominican Republic, Ecuador, El Salvador, Guatemala, Bolivia, Chile and Peru display a high involvement of the military with policing. The military forces were intensively deployed in police tasks to ensure the compliance of the lockdowns (RESDAL, 2020). The aforementioned countries are under states of emergency and there are checkpoints across the national territories to control the movement of citizens. Troops patrol the streets, and in El Salvador and Guatemala, they may interrogate and detain those that violate the lockdown measures in custody facilities.

Colombia, Paraguay and Mexico present intermediate levels of militarization in police tasks. Although military officers have some involvement with citizens, they are playing a secondary role to the police in ensuring compliance with lockdowns or stay-at-home orders. In contrast, the military in Brazil and Argentina have had a low involvement with policing during this pandemic, which means military forces are deployed in public security only in support to police bodies (aerial surveillance, technical support to intelligence services) (Argentina) or in informative campaigns between cities, especially in rural areas (Brazil) (Gröhs et al., 2020; Ybarra, 2020).

What are the potential consequences of involving the military in policing tasks during the responses to COVID-19? Where the military enforced emergency laws, human rights organizations have 
reported abuses. In Chile, military personnel shot a civilian that tried to avoid a military checkpoint and abandoned a civilian in the desert as a punishment for violating the lockdown (Gamboa, 2020). In Bolivia, military troops are repressing anti-hunger protests that are mushrooming in the cocaleros region (Radio Cawsachun Coca, 2020). In El Salvador, 206 complaints of human rights violations were filed at the Federal Prosecutor's Office of Human Rights, as security forces are arbitrarily detaining hundreds of people (Human Rights Watch, 2020).

In Honduras, local NGOs reported the repression of 106 peaceful protests since the onset of the lockdown, and of Guatemala citizens violating the stay-at-home order who were detained under inhumane conditions (Amnesty International, 2020). In Ecuador, until April 27, 2020, the Defensoría del Pueblo received 4618 reports of human rights abuses throughout the country (Defensoría del Pueblo de Ecuador, 2020). In Peru, the military were granted immunity for their actions during the state of emergency (Gobierno de Peru, 2020). These findings are consistent with the expectations of the literature on civil-military relations when considering the adoption of new missions by the military; thus, when the military is in charge of policing and activities that differ from their built-in organizational capacities, misdeeds and misbehavior are likely to occur.

\section{CONCLUSION}

This paper sought to map out the use of the military in Latin America as a response to the global pandemic of COVID-19. We developed a typology of militarization of government responses to COVID-19, while also collecting descriptive evidence of the different dimensions of militarization included in our typology. Latin American democracies have, without exception, militarized to some degree their response to the pandemic, though with considerable variation. We highlighted that some of these tasks hold potentially pernicious consequences.

In line with the literature on military missions, militaries tend to be less harmful if they are tasked with missions that are closer to their built-in organizational capabilities. Therefore, policing missions, such as in the Dominican Republic, Ecuador, El Salvador, Guatemala, Bolivia, Honduras Chile, Peru, and the assignment of crisis-management positions to the military, such as in Brazil, Chile, Bolivia and Peru, can entail harmful consequences. Deploying the military in an array of police tasks generates a short-term degradation of the human rights situation and aggravates the existing issue of police violence. Delegating military officers with crisis-management positions entails a less visible, yet perhaps negative impact for the capacity of civilians to control the armed forces in the medium and long terms.

Our contribution starts a research agenda on the topic of military missions in the context of the global pandemic. Additional research studying the causes of the variation in degrees of militarization of governmental responses to COVID-19 and its human rights consequences is warranted. Finally, scholarship interested in the military in Latin America should stay vigilant for the longer-term implications of these deployments for civil-military relations. 


\section{REFERENCES}

Acacio, I. (2020, March 26). Os Militares Podem Responder à Presente Crise? Horizontes Ao Sul. Retrieved from https://www.horizontesaosul.com/ single-post/2020/03/26/OS-MILITARES-PODEMRESPONDER-À-PRESENTE-CRISE

Agencia EFE. (2020, April 23). Laboratorio del Ejército colombiano procesará pruebas de coronavirus. Agencia EFE. Retrieved from https:// www.efe.com/efe/america/sociedad/laboratoriodel-ejercito-colombiano-procesara-pruebas-decoronavirus/20000013-4228480

Amnesty International. (2020, May 15). Las autoridades deben proteger a la población en lugar de recurrir a medidas represivas. Amnesty International Ltd. Retrieved from https://www.amnesty.org/es/ latest/news/2020/05/americas-authorities-mustprotect-people-covid19-repressive-measures/

Amorim, O., Neto. (2015). Democracia e relações civis-militares no Brasil. In L. Avelar \& A. O. Cintra (Eds.), Sistema Político Brasileiro: uma introdução (pp. 315-330). Rio de Janeiro, RJ/São Paulo, SP: Konrad Adenauer Stiftung/Editora Unesp.

Campbell, D. J., \& Campbell, K. M. (2010). Soldiers as Police Officers/ Police Officers as Soldiers: Role Evolution and Revolution in the United States. Armed Forces \& Society, 36(2), 327-350.

Defensoría del Pueblo de Ecuador. (2020, May 02). La Defensoría del Pueblo trabajará com la Comissión Interamericana de Derechos Humanos em acciones conjuntas durante la emergencia sanitaria em Ecuador. Retrieved from https://www.dpe. gob.ec/la-defensoria-del-pueblo-trabajara-con-lacomision-interamericana-de-derechos-humanosen-acciones-conjuntas-durante-la-emergenciasanitaria-en-ecuador/

Diamint, R. (2015). A New Militarism in Latin America. Journal of Democracy, 26(4), 155-168.

Exército Brasileiro. (2020, April 03). Apoio à distribuição de cestas básicas em Aracaju (SE). Retrieved from http://www.eb.mil.br/web/ noticias/noticiario-do-exercito/-/asset_publisher/ MjaG93KcunQI/content/id/11293578

Fuerza Aérea de Repúblicana Dominicana. (2020, April 12). Ministerio de Defensa instala en el Hospital Militar Docente FARD. Retrieved from
http://fuerzaaerea.mil.do/Noticias/Articulo/ ArticleId/3419/Ministerio-de-Defensa-instala-enel-Hospital-Militar-Docente-FARD-«Dr-Ramonde-Lara»-tunel-de-desinfeccion-ante-COVID-19

Gamboa, P. S. (2020, March). Arica: Fiscalía interrogó a militares que balearon a conductor en toque de queda. Retrived from http://www.lanacion.cl/ arica-fiscalia-interrogo-a-militares-que-balearona-conductor-en-toque-de-queda/

Gobierno de Peru. (2020) Ley de protección policial $L E Y$ - N. 31012, El Peruano - Diario Oficial. Retrieved from: https://busquedas.elperuano. pe/download/url/ley-de-proteccion-policial-leyno-31012-1865203-1

Gobierno del Perú. (2020, April 08). Instalan Comando de Operaciones Covid-19 en Loreto. Retrived from https://www.gob.pe/institucion/pcm/ noticias/112105-instalan-comando-de-operacionescovid-19-en-loreto

Grigoli, G., Silva, J. \& Migon, E. (2020, April). O Exército Brasileiro e a resposta à Pandemia da Geração de Capacidades no Comando Conjunto Leste (pp. 1-7). Military Review.

Grimes, Collin; Pion-Berlin, D. (2019). Power Relations, Coalitions and Rent Control: Reforming the Military's Natural Resource Levies. Comparative Politics, 4, 625-643.

Gröhs, M., Biavaschi, E., \& Rodrigues, K. F. (2020, May). Forças Armadas e Capacidade Relacional na Operação COVID-19 (pp. 1-7). Military Review.

Human Rights Watch. (2020, April 17). El Salvador: President Defies Supreme Court. Retrieved from https://www.hrw.org/news/2020/04/17/el-salvadorpresident-defies-supreme-court

Lago, M. (2020, March 19). América Latina Puede Convertirse En La Mayor Víctima Del COVID-19. New York Times. Retrieved from https://www. nytimes.com/es/2020/03/19/espanol/opinion/ coronavirus-america-latina-gobiernos.html

Listín Diário. (2020). COVID-19 - Ejército refuerza la frontera com 600 militares por el Coronavirus. Retrieved from https://listindiario.com/larepublica/2020/03/19/609394/ejercito-refuerza-lafrontera-con-600-militares-por-el-coronavirus 
Loveman, B. (1999). For la Patria. Politics and the Armed Forces in Latin America. Wilmington, Delaware: SR Books.

Ministerio de Defensa de Peru. (2020a, April 06). Ministro de Defensa dispuso redoblar en control de todas nuestras fronteras. Retrieved from https:// www.gob.pe/institucion/mindef/noticias/112015ministro-de-defensa-dispuso-redoblar-el-controlde-todas-nuestras-fronteras

Ministerio de Defensa de Peru. (2020b, April 04). Presidente Vizcarra presentó equipo de respiración artificial desarrollado por la Marina de Guerra. Retrieved from https://www.radionacional.com.pe/ noticias/politica/presidente-presento-equipo-derespiracion-artificial-desarrollado-por-la-marinade-guerra

Ministerio de Defensa del Estado Pluracional de Bolivia. (2020, April). Entregan alimentos y enseres a ciudadanos albergados en campamento Tata Santiago en Pisiga. Retrieved from https://www.mindef.gob. bo/mindef/node/4058

Ministerio del Interior y Seguridad Pública de Chile. (2020). Declara Estado de Excepción Constitucional de Catástrofe de Calamidad Pública en el Território de Chile, Diario Oficial de la República de Chile, Chile.

Our World in Data. (2020). Research and data to make progress against the world's largest problems. Retrieved from https://ourworldindata.org/

Passos, A. M. (2020). Breaking the Law to Ensure Order: The Case of Tijuana (2007-2012). Bulletin of Latin American Research, Early View, 1-16.

Pion-Berlin, D. (2016). Military Missions in Democratic Latin America. New York, NY: Palgrave Macmillan.
Presidencia de la República de Colombia. (2020, 24 March). Las Fuerzas Militares y la Policía Nacional están desplegadas en el territoria nacional con el fin de "hacer cumplir" la medida del Aislamiento Preventivo Obligatorio por el COVID-19 afirmó el Ministro de Defensa. Retrieved from https://id.presidencia.gov. co/Paginas/prensa/2020/Fuerzas-Militares-PoliciaNacional-cumplir-medida-Aislamiento-PreventivoObligatorio-COVID-19-Ministro-Defensa-200324. aspx

Red de Seguridad y Defensa de América Latina. (2020). La Labor de Fuerzas Militares en el Contexto de Crisis Covid-19. Retrieved from https://www. resdal.org/assets/Boletin_COVID.pdf

Saint-Pierre, H. L. (2007). Controle civil sobre os militares e política de defesa na Argentina e no Brasil. São Paulo, SP: Ed. Unesp.

Saumeth, E. (2020, April 04). Las Fuerzas Armadas de Colombia apoyan labores humanitarias frente al Covid-19. Retrieved from https://www. infodefensa.com/latam/2020/04/04/noticiacovid19colombia81es-fuerzas-armadas-colombianasapoyan-labores-humanitarias-medio-covid.html

Vargas, M. (2020, May). Centrão entra na Saúde e militares devem ganhar 20 cargos. Retrieved from https://www.terra.com.br/noticias/brasil/politica/ centrao-entra-na-saude-e-militares-devem-ganhar20-cargos,aceb6b87c2a9f87ebc3558c79adc0a742m 6c30l9.html

Ybarra, G. (2020, April). Coronavirus en la Argentina: Agustín Rossi dijo que las Fuerzas Armadas desplegaron el "operativo más importante desde Malvinas". La Nación. Retrieved from https:// www.lanacion.com.ar/politica/rossi-dijo-fuerzasarmadas-desplegaron-operativo-mas-nid2358960 
RAP | The militarization of responses to COVID-19 in Democratic Latin America

\section{WEBSITES}

Argentina: Retrieved from https://www.argentina. gob.ar/defensa

Bolivia: Retrieved from https://www.mindef.gob.bo/ mindef/node/4044

Brazil: Retrieved from http://www.eb.mil.br/ combate-ao-covid19

Chile: Retrieved from https://www.defensa.cl

Colombia: Retrieved from https://id.presidencia. gov.co/

Dominican Republic: Retrieved from https://www. ejercito.mil.do/

Ecuador: Retrieved from https://www.defensa.gob.ec/
El Salvador: Facebook and Twitter @DefensaSV and @FUERZAARMADASV

Guatemala: Retrieved from https://agn.gt/

Honduras: Retrieved from https://sedena.gob.hn/

Mexico: Retrieved from https://www.gob.mx/ sedena/prensa/

Paraguay: Retrieved from http://www.mdn.gov.py/ index.php/noticias/

Peru: Retrieved from https://www.gob.pe/ institucion/mindef/noticias/

Uruguay: Retrieved from https://www.gub.uy/ ministerio-defensa-nacional

\section{Anaís Medeiros Passos}

https://orcid.org/0000-0001-8028-8523

PhD. In Political Science at Sciences Po Paris; Assistant Professor in the Department of Sociology and Political Science of Universidade Federal de Santa Catarina; Post-Doctoral Researcher at Institute of International Relations at University of São Paulo (IRI-USP).E-mail:anais.passos@ufsc.br

\section{Igor Acácio}

https://orcid.org/0000-0001-9998-0683

Ph.D. Candidate in Political Science at the University of California, Riverside; University of California Institute on Global Conflict and Cooperation (IGCC) Dissertation Fellow; Visiting Researcher at the Center for the Research and Documentation of Contemporary Brazilian History at the Getulio Vargas Foundation (FGV CPDOC).

E-mail: ipalh001@ucr.edu 